\title{
AIMS AND CONTENT OF SIXTH-FORM TEACHING
}

CONCERN about the aims and content of present. 1 day sixth-form teaching in Britain's schools was expressed in London recently at three conferences for schoolmasters organized by the British Petroleum Co., Ltd., and held during November and December. In particular, mathematics, chemistry and the arts came under review.

\section{Mathematics}

The first of the conferences examined the problems arising in the teaching of mathematics and referred to the use made of mathematics, in its widest applications, by industry. It was attended by about fifty mathematics masters from all parts of Great Britain, chiefly from public and grammar schools, but representing also other schools and colleges of technology. The masters set out to consider the relationship of syllabus, examination, career and mathematical attitude, with the intention of focusing on sixth-form studies.

Mr. J. T. Combridge, president of the Mathematical Association, was the chairman of the meeting. The principal speakers were Mr. M. F. Robins (Rugby School), Mr. B. A. Edwards (King's College, London), Mr. E. K. Frankl (University of Cambridge), Mr. E. S Sellers, Mr. P. B. Coaker and Mr. A. Battersby (British Petroleum), and Mr. W. M. Brookes (University of Southampton).

The conference decided that the matter was not one for sixth-form teaching alone but was bound up with teaching at all ages from the primary school onwards. It called for a committee, composed of representatives from industry and from schools of every kind, to make recommendations regarding the content of the mathematies to be taught in schools at all levels. It suggested that through the Mathematical Association there should be brought about regular meetings between similar representatives, organized on a local basis, and the establishment of regular opportunities for discussion between teachers of mathematics in universities and schools.

Concern was expressed about the desperate shortage, not only of teachers of mathematics but also of people in all occupations sufficiently competent in the use and appreciation of mathematics. The conference considered that one cause was the excessive competition for places in universities, as this was having the effect of deterring boys from proceeding to mathematics at the Advanced Level of the General Certificate of Education except in so far as the subject might be necessary for a career in another science or in engineering. Consequently, both the high standards of scholarship and entrance examinations, and the inadequate number of university places in mathematics, come in for criticism.

It was urged that more places should be found next autumn for mathematics students, even at the expense of places for undergraduates in arts subjects. More support, as a temporary measure, for one-term courses for serving teachers not trained for mathematics teaching but required by the present shortage to undertake it was also suggested.

Reasonable restraint on the part of industry and the Government in the use of mathematicians was also urged; was it not possible for each employer to tighten his belt without loss of efficiency? The conference also considered that there is need for university degree courses in mathematics which, at any rate after the first year, would not be specialized enough for the specialist mathematician who might hope to go on to research, but which would be adequate for anyone who has the ability to go into industry as a mathematician rather than as an engineer or scientist.

Despite the unavoidable attention demanded by modern mathematics and notwithstanding its importance as a tool of industry, the conference placed on record its view that the supremacy of mathematics as a means of education, in its widest sense, must be recognized and maintained.

\section{Chemistry}

The second conference was designed to provide a forum in which school chemistry teachers could discuss their professional problems among themselves and with representatives of the various bodies who were interested in the general question of the education of chemists. Some forty-five schoolmasters from public and grammar schools attended this conference.

The chairman was Dr. F. N. Brewer, head of the Department of Inorganic Chemistry (University of Oxford). Among those who addressed the conference were Sir Harry Melville, secretary of the Department of Scientific and Industrial Research; Dr. J. E. Spice (Winchester College), Dr. A. Sharpe (University of Cambridge), Dr. W. Gerrard (Northern Polytechnic), Mr. E. S. Sellers (British Petroleum), Dr. Van Praagh (Christ's Hospital), Dr. J. A. Petch, secretary of the Northern Universities Joint Matriculation Board; and Mr. D. W. Hutchings (University of Oxford).

In introducing the conference, Sir Harry Melville emphasized that chemists were coming to occupy a key role in the modern world. This was true not only in the context of their own subject (and this could lead into many unsuspected fields), but also in the wider fields of administration and management for which their flexible yet precise training could fit them admirably. At all levels it was important to select the basic matter to be taught and to teach it in such a way that relevance was attained and flexibility of mind encouraged.

Present teaching methods, the influence on teachers of the requirements of the universities and of the examining Boards, the outlook and development of the industrial chemist, and the position of chemistry in a possibly wider syllabus such as is common in some Continental countries were discussed. In particular, the recent recommendations of the Science Masters' Association and the Association of Women Science Teachers for syllabus revision were subjected to a very critical scrutiny and the conference was able to clarify various points with the members of the Joint Panel of the two Associations who were present. 
No. 4817 February 24, 1962

Arts

The aim of the third conference was to examine the position of the arts student in a society which is apparently becoming more and more technological in emphasis, and in particular to consider the value and relevance of the traditional approach to an arts education.

About forty teachers from grammar and public schools attended this last conference, of which the chairmen were Mr. A. D. C. Peterson, director of the University of Oxford Department of Education, and Mr. K. Charlton of the University College of North Staffordshire.

Other speakers included Prof. W. H. G. Armytage (University of Sheffield), Mr. H. S. Mullaly (British Petroleum), Mr. D. W. Hutchings (University of Oxford), Dr. A. E. Bell (Cheltenham Grammar School), and Mr. Hugh P. Ramage of the Science Masters' Association. The closing address was given by Dr. F. A. Vick, director of the Atomic Energy Researeh Establishment.

In introducing the conference, Mr. Peterson touched on the very early polarization into 'arts men' and 'science men' that took place in Britain, the almost total exclusion of the rsthetic arts from our school syllabuses and the minute resources that were allocated to educational research. But he was primarily concerned with the vital areas of communication and human behaviour, and here he saw serious shortcomings in such fields as mathematics and language teaching.

Mr. Charlton sketched the historical development of the arts education while Prof. Armytage outlined the pressures that were changing our total environment-cheap power, the computer revolution, the growth of the chemical industry and the growing power to manipulate opinion. The employment of arts graduates in a large organization was discussed by Mr. Mullaly, while Mr. Hutchings spoke on the general question of whether science should, or could, be taught to arts students; Mr. Ramage explained the proposals of the Science Masters' Association in this field. Dr. Bell described the work he was already doing in his school, and to wind up the conference, Dr. Vick surveyed and illuminated the outlook and methods that contribute to the scientific imagination.

Though the conference was convinced of the value of an arts education in the formation of values and as a guide to human behaviour in all its complexity and in all fields of human endeavour, it accepted the view that the arts student should be helped towards an understanding of modern science and its methods and philosophy. It deplored the existence of the 'two cultures' in education and called for the elimination of this concept, both in thought and in practice. But the introduction of any serious scientific study into the sixth-form arts curriculum would raise very considerable difficulties of programming and staff and complicate yet further this serious situation in science teaching. In particular, some members of the conference felt that teachers of arts subjects should in some way evolve a negotiating body that could discuss with the Science Masters' Association the possible introduction of scientific studies.

During all three conferences, the theme that emerged was that of 'relevance': not relevance in any narrow vocational or materialist sense but relevance to life as lived in a society where modern science and technology are dominant social forces. It is necessary to understand these forces, whether to co-operate with them or to resist them.

\section{OCEANOGRAPHY IN LATIN AMERICA} FOUR meetings were recently held in Chile con-
cerning oceanography and its research development in Latin America. They were: (1) a Latin American seminar of oceanographic studies; (2) the second Latin American Symposium on Plankton; (3) a meeting of directors of Latin American coastal laboratories; and (4) a regional training course on marine biology. They were organized jointly by the Unesco Science Co-operation Office for Latin America and, in the case of (1) and (2), the University of Concepcion, and, for (3) and (4), the University of Chile, and held, respectively, in the General Biology Laboratory (Concepción) and Marine Biology Station (Montemar).

Thirty-seven Latin American scientists participated, coming from Mexico, Colombia, Venezuela, Brazil, Uruguay, Argentina, Chile, Peru and Ecuador. Observers were present including: Dr. D. L. Ray, from the National Science Foundation (United States); Dr. P. Dohrn, from the Stazione Zoologica di Napoli (Italy); Dr. W. Branhorst, chief of the Federal Republic of Germany Technical Assistance Programme to Chile; and Dr. F. Ottmann, from the Institute of Marine Biology, Recife (Brazil). Dr. R. Margaleff (Spain) was present, by special invitation, at the Symposium on Plankton. In the first meeting, Dr. P. Roa Morales (Venezuela) was elected chairman for the Abiotic Section, and Dr. F. de Buen (Chile) for the Biological Sections and also for the directors' meeting. Dr. R. Margaleff (Spain) was invited to act as chairman of the Symposium on Plankton, and for the regional training course Dr. F. de Buen and Dr. E. Rioja (Mexico) acted as co-directors, with the assistance of scientists from Mexico, Chile, Uruguay, Argentina and Brazil. (This course was attended by more than twenty students from Latin American countries.) In all these meetings, Dr. H. Ferrando (Uruguay) acted as secretary.

The main purpose of these meetings was to make an evaluation of the actual standing of research in marine sciences in Latin America in the light of what has been accomplished; accordingly, a series of valuable reports was submitted by leading scientists from Latin America, covering the different disciplines of marine sciences. It was also felt that some decision should be taken so as to increase the existing knowledge through research and training, primarily on a co-operative regional basis.

Among the most outstanding points arising from the adoption of resolutions and recommendations made at the meetings were the following:

(1) The creation of a Latin American Council on Oceanography, with the election of its steering committee composed of leading marine scientists from Mexico, Venezuela, Uruguay, Argentina, Chile and Brazil, under the chairmanship of Dr. F. de Buen. 